\title{
Vision 2020: Hydropower - A Vision for Growth
}

The Federation of Nepalese Chamber of Commerce \& Industry (FNCCI) organized a one day national seminar on Vision 2020: Hydropower-A Vision for Growth on 24 November 2008 in Kathmandu, Nepal. The seminar was co-sponsored by the Nepal Electricity Authority (NEA) and Hydro Solutions and was inaugurated by the Minister of Water Resources, Mr. Bushnu Poudel. The main objective of the seminar was to assist the Government of Nepal (GON) in fulfilling the ambitious target of developing 10,000 MW of hydroelectric power in the next ten years.

The seminar was attended by prominent business persons, government officials, policy makers, hydropower and water resources experts, developers, bankers and foreign dignitaries. The participants discussed the mode of developing projects, the necessary internal and external financial resources, and formulation of a plan to move forward to achieve the target.

Mr. Poudel informed the seminar participants that the GON is in the process of formulating an action plan for the development of 10,000 MW in next 10 years. He further stated that the GON has submitted a draft bill for creation of the proposed Electricity Act and Nepal Electricity Regulatory Commission (NERC) to the parliament, which will be implemented soon.

Mr. Kush Kumar Joshi, President of FNCCI, requested the creation of an environment conducive to effective publicprivate partnerships for hydroelectric power development in Nepal. He stated that due to the present energy crisis, the productivity of Nepalese industries has declined, which in turn has affected negatively on the national economy.

Mr. Gynanedra Lal Pradhan, Chairman of the FNCCI's Hydropower Forum, stated that Nepalese industries have lost productivity equivalent to NRs. 250 billion during last five year period.

Mr. Sriranjan Lacoul, Director General of the Department of Electricity Development (DoED), Mr. Sher Singh Bhat, Director of NEA, Mr. Gyanendra Lal Pradhan of FNCCI and Mr. Jean-Marc Carpentier, President of White Mountain Energy (Canada) presented papers on Vision 2020 to the seminar.

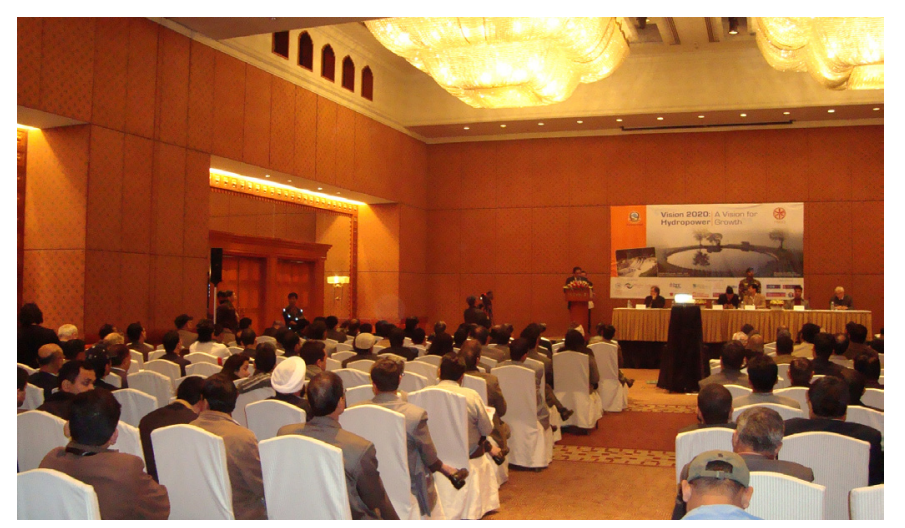

HYDRO Nepal, the publication of the Environmental Resources Group (P) Ltd., together with URJA Nepal were media partners for the event. This issue of HYDRO Nepal contains the abstract of the papers presented by the experts in the seminar.

\section{Power Map of Nepal}

Hydro Solutions launched the Power Map of Nepal at the national seminar. The Power Map of Nepal is a first of its kind wall map that fulfills the necessity of an all-inclusive atlas of Nepal's water resources, geographical and district demarcations, as well as the power stations, all illustrated in one frame. The map also embraces the hydroelectric power projects whose licenses have been issued by the GON. It also indicates major transmission lines of India in the border areas. The Power Map of Nepal is available at Hydro Solutions and leading book stalls in Nepal for $\mathbf{5 0 0}$ rupees.

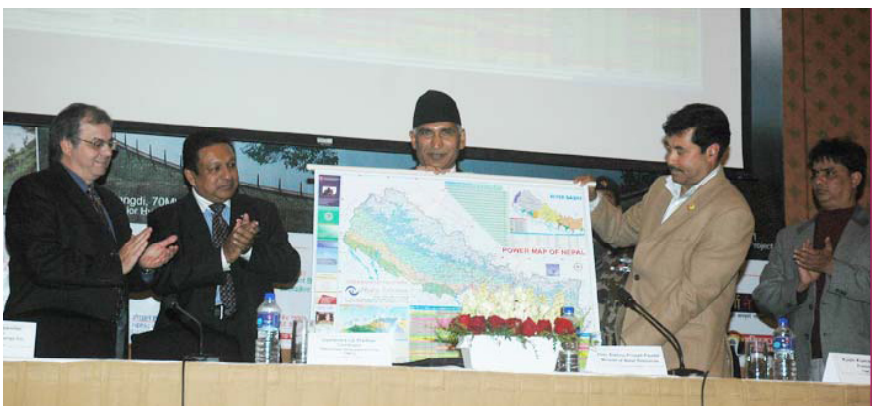

\section{Four Papers were presented in the seminar Vision 2020; the abstract of which are given below}

\section{Vision 2020: Hydropower A Vision for Growth \\ Gyanendra Lal Pradhan Chief Strategist, Hydro Solutions}

To realize the highly ambitious target of hydro-electric power generation of $10000 \mathrm{MW}$, there must be a plan for implementation at war footing with identified projects and its modalities for implementation. It should have a clear start and end dates. FNCCI is anxious to cooperate with Nepal Government in preparing an overall plan for developing 10000 MW of Hydropower by 2020. The South Asia market is ready for export of Nepali hydro-electric power.

The present scenario of energy use consists of $78 \%$ fuel wood, $9 \%$ petroleum and less than $2 \%$ electricity that must be reversed with increased electricity production. The present capacity available is $598 \mathrm{MW}$ in wet and $360 \mathrm{MW}$ in dry season. The prevailing energy crisis must be minimized.

The present load shedding is expected to be continued for several years to come. The productivity loss due to 
load shedding is whopping NRs. 59 Billion in 2008 which will increase in future. Furthermore, Nepal - India trade imbalance is enormous NRs. 76 Billion in 2006 and growing (NRs. 105 Billion at present- Ed.). Large scale hydropower development is an answer to these problems.

Vision 2020: Hydropower needs to be formulated with major stakeholders such as Nepal Planning Commission, Ministry of Water Resources, Nepal Electricity Authority (NEA), Department of Electricity Authority (DOED), Foreign Direct Investment, Environments and Forests Departments, political parties etc. It is proposed to make preliminary preparation in 2009 and start implementing the projects from Jan 2010.

We need to develop bilateral projects including Karnali Chisapani. Basin wise transmission plan should be prepared and implemented.

\section{Vision 2020: A Perspective}

Sriranjan Lacoul, Director General Department of Electricity Development (DoED)

The Government of Nepal has set forth a target of $10000 \mathrm{MW}$ of hydropower development in next 10 years. The present status of hydropower generation is $547 \mathrm{MW}+70 \mathrm{MW}$ and 89 MW of under construction projects. There are no shortages of projects for the fulfillment of the target of 10,000 MW. The survey license issued is $7100 \mathrm{MW}$ whereas $5000 \mathrm{MW}$ (> $10 \mathrm{MW}$ ) is under process i.e. about $13000 \mathrm{MW}$ in total. The government will prioritize the projects through a committee with involvements of stakeholders. However, mega projects (multi purpose) may not be included. The money required for the vision is NRs.1 trillion (NRs.10 kharab) for generation and another NRs.1 trillion for transmission line.

Government is in process of passing the Electricity Act and Nepal Electricity Regulatory Commission Act. The Electricity Act will create forward looking measures in development of electricity. The Regulatory Act will create an independent commission for regulation of the sector by creating a level playing field for all players. There are challenges for development such are;

- lack of investment friendly environment;

- local peoples unjustified demand and expectations;

- overall security situation;

- confusion on country's political regime;

- capability to facilitate the developers;

- market development;

- development of other related infrastructure; and

- many more

The major threats are perception of political risks and claim on resources due to near future federal system of governance. Developers need to be ascertained by the deeds of the party and the government. To summarize, the target of $10,000 \mathrm{MW}$ is achievable by everybody working together towards the mission.
Vision 2020: Hydropower

Sher Singh Bhat

Director, System Operation Department Nepal Electricity Authority

Nepal can be prosperous by using hydropower as its national competitive advantage. The vision should be "Nepal as major energy exporting country of South Asia by 2020 ". The mission should be;

- 10000 MW of Hydropower development;

- export after fulfillment of domestic requirements;

- every household having access to electricity;

- major contribution in GDP through hydropower; and

- most mineral fuel based energy is substituted by electricity

Year 2009 should be utilized for planning and implement the project from Jan 2010 to 2020. Projects can be developed by private, public, with FDI fund, bilateral etc. It is immaterial who is the developer; the basic issues are a) best and the cheapest projects to be developed first, b) projects developed in the best interest of the country. The issues are lack of transmission resource optimization, system balancing against seasonal variations, market model, and dual state policy for social and economic tariff. The NEA will have special role to fulfill the vision of the nation on hydropower. However, the NEA does not get special privileges, even though NEA is expected to promote everybody for benefits without increasing tariff.

NEA will play a leading role as developer, system operator, transmission operator, distributor including cross border energy exchange. Once the government has identified target projects, a master plan needs to be prepared for generation and transmission.

Vision 2020: Hydropower is bound to make Nepalese prosperous by exploiting the competitive advantages of our resources.

\section{The Canadian Experience through Hydropower}

\author{
Jean-Marc Carpentier, President \\ White Mountain Energy \\ Montreal, Canada
}

The Canadian Experience will be meaningful to Nepal as the context is same and the potential is also nearly the same. Large scale Hydropower was developed in Quebec province of Canada about a century ago. Quebec model is suitable for Nepal. In 1950-2000 context the fuel price was low as $\$ 3$ per barrel, interest rate was high, and potential for export was minimal. In present context the conducive environment is high. Hydropower has the potential for social and political development. The fundamental goals are development of country in creating economic activities and sustained wealth production base. Due to very high concern of $\mathrm{CO}_{2}$ emissions and climate change, hydro power importance has increased tremendously. As it is capital intensive and the infrastructure 
will last century; it is done once, it must be done right. The following are some of the important points that need serious considerations:

- Maintain stable political and economic environment;

- A consensus on Hydropower Strategy;

- Infrastructures should be built with a master plan;

- We should not sell out water resources indefinitely;
- $\quad$ Electricity should be priced at its market value; and

- $\quad$ Prepare a Master plan and start the work.

White Mountain Energy has a partnership with LEDCO, Butwal Power Company, and the Khudi Project, of Nepal, and is working to bring high level expertise and to develop medium to large hydro projects in Nepal. 